\title{
Assessing Embedded Agency of Entrepreneurs in Context of Internationalization and Innovation: An Exploratory Research
}

\author{
Xavier Lesage \\ ESSCA School of Management, LUNAM University \\ 01, Rue Lakanal, BP40348, 49003 Angers cedex 01, France \\ Tel: 33-2-4173-5773 E-mail: xavier.lesage@essca.fr \\ Sébastien Ronteau (Corresponding author) \\ ESSCA School of Management, LUNAM University \\ 01, Rue Lakanal, BP40348, 49003 Angers cedex 01, France \\ Tel: 33-2-4173-5767 E-mail: sebastien.ronteau@essca.fr
}

Received: September 9, 2011

Accepted: April 16, 2012

Published: June 1, 2012

doi:10.5539/ibr.v5n6p62

URL: http://dx.doi.org/10.5539/ibr.v5n6p62

\begin{abstract}
"Tradition is a continuous process of innovation". This sentence is a leitmotiv for Kotaro Nishibori, one of the last Japanese entrepreneurs in the wagasa sector (Japanese traditional umbrellas). Based on the symbolic path of this entrepreneur, this exploratory research investigates embedded dynamics in which the entrepreneur involves himself and his firm, and which conduct a simultaneous two-sided development of its traditional workshop to a global firm acting by/on a continuous innovation process. Based on a neo-institutional framework and literature on entrepreneurial bricolage, we reveal few insights regarding entrepreneur's embedded agency. As the entrepreneur involves himself in social networks, he gets access to resources, which reveal his proactive competencies and in return extend his network. Globalization process based on continuous innovation of Small and Medium-sized Enterprises (SME) can be viewed as the result of strategic trial and error process, in which the entrepreneur plays a critical role.
\end{abstract}

Keywords: Globalization, Innovation, SME, Agency, Entrepreneurial bricolage

\section{Globalization and Innovation in Context of SMEs}

Many researchers pay attention to the value of innovation in internationalization strategies of SMEs (Dana, 2004; McDougall \& Oviatt, 2000; Coviello \& McAuley, 1999). On one hand, some of them focus on innovation as a trigger in globalization process. In order to make quick returns on huge investments, SMEs engage themselves in global competition. On the other hand, the same considerations are observed in context of "born global" organizations (Rialp et al., 2005; Knight \& Cavusgil, 2004; Sharma \& Blomstermo, 2003). The adoption of a multi-market strategy from the beginning is strongly motivated to balance investments on research and development underlying products or technologies innovations. However, few research projects follow in return the impact of globalization on innovation process of SMEs. Is there a virtuous dynamic or a vicious circle regarding innovation as the SME goes global? What is the implication of the entrepreneur in such developments? Researchers from the recent School of 'International Entrepreneurship' have some difficulties to overcome with the 'Uppsala Model' (Johanson \& Vahlne, 2009). Their research frameworks are based on a sequential process of globalization with incremental learning (Keupp \& Gassmann, 2009; McDougall \& Oviatt, 2000). Even empirical studies remain anchored to SMEs with quick and forward globalization developments without any consideration to the central position of the entrepreneur (owner) in both globalization and innovation decision making process (Bacq \& Coeurderoy, 2010).

\subsection{Decision-making Process in Context of SME}

In context of SME, the decision-making process is intrinsically linked to the owner - the entrepreneur as the only decision-maker - and its perception of how overseas or innovative opportunities may impact present and future activities. In such context, involvement in growing strategies - globalization and innovation - is conducted under consideration of scarce resources. Both globalization and innovation are expensive, time consuming and significant 
drains on those scarce resources. As many researchers pointed it out, the relative importance and role of decision-makers within growth strategies processes depends on theoretical backgrounds and frameworks: network relationships approaches and innovation-related stage theory support the view that individual decision-makers play a pivotal role rather than the scale internationalization theory relegates the importance of decision-makers in favor of an economic, transactional based rationale, although none of those considerations have not been yet adequately tested (Collinson \& Houlden, 2005). Shared by those theoretical backgrounds, knowledge accumulation and feedback seem to play an important role in decision-making process. But as some researchers mentioned that for the internationalization process, experiential knowledge is more relevant than objective knowledge (Johanson \& Vahlne, 1977, 1990). Accordingly, even innovation process or international strategies reveal trial-and-error strategic path for entrepreneurs. And in this vein, it supports McGaughey, Welch and Welch conclusion (1997: 176): "the experience and personal characteristics of small firm owners have been shown to have significant impact on firm performance". Based on a qualitative and quantitative study of 30 SMEs in UK, Collinson \& Houlden (2005) support that idea and demonstrate that "international experience and network relationships are found to strongly influence managerial cognition and thereby internationalization decision-making. The learning process appears to be unstructured and opportunistic." (Collinson \& Houlden, 2005: 413).

\subsection{Embedded Agency and Entrepreneurial Bricolage}

The network perspective of decision-making in context of SME supports the idea that opportunities (both internationalization and innovation) are produced through a social-construction process and cannot exist under consideration of the individuality of the entrepreneur (Shackle, 1979; Baker \& Nelson, 2005). To assess this process, which gives life to opportunities, two streams of literature seem relevant. Neo-institutional literature tries to overcome the paradox of embedded agency (Battilana \& D'Aunno, 2009; Greenwood \& Sudaby, 2006; Dorado, 2005; Seo \& Creed, 2002; Beckert, 1999; Holm, 1995). To do so, researchers introduces a theory of institutional entrepreneurs, which confer to specific actor in an institutional field abilities to overcome institutional rules and gain access to a more confortable position. Central to this theory, researchers mobilize the concept of embedded agency. The power of action of such institutional entrepreneurs and their transformational capabilities depends on their social networks and assets they are able / decide to leverage. The impact of their embedded agency depends on their capacities to make sense creatively and voluntarily of new combinations of resources (Dorado, 2005). Accordingly, three processes underlie entrepreneurs' embedded-agency: resources accumulation; discursive strategies to involve partners to support changes; various strategies and maneuvers to maintain partners' involvement (Delemarle, 2007).

Even if the empowerment of an embedded agency capability is well depicted by researchers, less attention is paid to emerging processes of such embedded agency. To stress on the initial point of development of awareness for decision-maker of its embedded agency, we decide to refer to a second set of literature dealing with 'entrepreneurial bricolage' (Baker \& Nelson, 2005; Garud \& Karnoe, 2003). According to this stream of literature, in context of scarce resources, entrepreneurial bricolage processes are at work when entrepreneurs render unique services (create something from nothing) by recombining elements at hand for new purposes that challenged institutional definitions and limits (Baker \& Nelson, 2005).

Accordingly, the decision-making process combining globalization and innovation developments in context of SME seems to go through a path of opportunistic and network-based processes in which the entrepreneur, by its pivotal position, plays a central role. Those entrepreneurial bricolage processes, in which the entrepreneur engages himself, are part of the development of an embedded agency on which success depends to maintain and develop a virtuous circle of internationalization and innovation. This research proposition needs now to be tested.

\section{Hiyoshiya: "Tradition Is a Continuous Process of Innovation”}

\subsection{The Extended Case Method}

In order to gain insights on the importance and role of entrepreneurs in globalization and innovation processes, an inductive approach was used, drawing on a single symbolic case study of a Japanese traditional wagasa workshop. Our approach was exploratory and anchored in the 'extended case methodology' which aims to use substantial empirical data collected through a case study to re-conceptualize and extend existing theories (Burawoy, 1998; Danneels, 2002). In that effort, we leaned on a theoretical framework at the crossroads of several fields international entrepreneurship, embedded agency, entrepreneurial bricolage - to construct a plausible understanding for underlying processes of importance and role of entrepreneurs in decision-making process of both globalization and innovation developments of their SMEs.

\subsection{Data Collection}

Our choice fell on a single case study on which we had the opportunity to collect a large amount of data (primary and secondary) and to monitor in situ the strategic trial-and-error process of the entrepreneur. Given the emerging 
nature of the research proposition that we weave, the single case study seemed well suited to understanding a complex phenomenon in its anchored context (Eisenhardt, 1989). Moreover, the amount of data and longitudinal analysis that we conduct can respond fully to the exploratory nature of our research. Finally, the validity of the case is not statistical but more analytical in that it sticks to the nature of our exploratory research mobilizing a symbolic event, rare and revelatory (Yin, 1990). Our method of data collection depends first and foremost on a close interaction with the entrepreneur who allowed us to retrospectively trace the evolution of his workshop over the past five years (2006-2011). For more than a year now, formal and informal meetings were held in France and Japan, punctuated by regular phone interviews every fortnight on past three months. The talks since February 2011 were recorded and transcribed; since then, the evolution of the firm has been recorded in a logbook. With the help of the entrepreneur, who opened his "archives", the corpus of data was filled by secondary data covering a longer period from 1997 to 2011. These were mainly of articles in the press, but also numerous internal documents, including keynote presentations he has made since 2005 as part of the project to export and internationally innovate. The use of different sources has allowed us to test the reliability of the evidence base through the degree of convergence found on the same traits (Campbell \& Fiske, 1959) and establishes data triangulation (Jick, 1979). Data analysis was conducted through a three steps coding: (1) free coding to reveal the chronology and key dimensions of the case; then (2) an axial coding according our theoretical background; and then a selective coding to reveal bricolage underlying processes. Having achieved an empirical saturation, our choice fell on a case presentation in two parts that allows us to recreate the complexity of phenomena embedded in their temporality (Gombault, 2006). We will proceed first to a reconstruction of events in time - diachronic dimension - and then discuss the phenomenon in its complexity to cast a critical eye on the research proposition previously made - synchronic dimension of our analysis.

\subsection{Data Analysis: A Diachronic Analysis of Entrepreneur's Emerging Agency}

Hiyoshiya is a time-honoured workshop founded in the Edo era (1600-1868). It has been making wagasa for 150 years using its know-how in working traditional materials mainly bamboo and washi paper. For this specific industry, 1950's can be considered as "the golden age", more than 14 million pieces were sold during the decade. Since the 1960's, wagasa's market share suddenly shrank following the introduction and proliferation of plastic-like umbrellas made in China: only one million pieces were sold in 1975; half a million in 2000; roughly 350000 in 2005. Consequently, the number of manufacturers fell dramatically from 450 to about 20 nationwide. In Kyoto, industry's birthplace, their number even shrank from 200 to only one survivor: Hiyoshiya.

Western umbrellas, mainly made in China, have now replaced the wagasa as western style dresses have replaced Japanese kimonos: surviving manufacturers now only respond to niche markets and specific needs such as tea ceremonies, theatre play or decoration purpose. Revenues decreased critically for averaging a million yen in 2010 . Among the surviving companies, Hiyoshiya has found and walked through a new path. Unexpectedly, the small company which only consists of 8 people, run by a 37 years old young retired from the local government - Kotaro Nishibori, has been succeeding in developing new products, not only umbrellas but luminaires and other interior design products, fusioning new technologies and new designs, to meet with the needs of the age. Unexpectedly, the time-honoured shop has become a global time-honoured venture within less than 5 years now showing the way to the other struggling companies.

\subsubsection{8-2008: A Trial-and-error Process of Diversification}

The K. Nishibori's story begins with his marriage with the heiress of the centenary family-run company. After 2 years of training and learning the whole process of making a wagasa, he quit the local government where he was in charge of the promotion of the city to take over the company.

The fifth-President stepped in with the extinction of neighbourhood umbrella shops in a dooming traditional industry. Without knowing exactly what to do, he knows he has to do something to help the company go through it. Firstly, $\mathrm{He}$ is enterprising the only thing he has ever learnt to do: promotion and communication. With the help of his younger brother, web designer student, he set up an Internet home page and further a whole website. Hiyoshiya was the first wagasa company to be online, which gave it a real competitive advantage with the advent of Internet in Japan; owning the domain name wagasa, it is still one of the best-referenced manufacturer website on Internet.

Beyond promoting the company image, K. Nishibori realizes that the survival relies on his ability to develop new products, and first of all new umbrellas. However, he knows that he is not able to compete with Chinese imported umbrellas; he has to think of something slightly different based on the only resource the company has: its tradition and long-lasting know-how.

Since 2002, K. Nishibori and his team undertook a long time-spending study to depict the key factors of success of the 1950's wagasa: the daily use and the multi-functionality (protection as well as element of decoration) of the 
product clearly established. During this period, he also learns a lot from competitors, and particularly from Fujisawa, an historical leader of the market, who stresses on the importance of design and the resulting capacity to offer customers diversified products with different shapes, materials, colors and motifs. Meanwhile, he and his team have been staying focused on their know-how and what made their products unique: bamboo ribs and the beautiful structure when opened. The result was an innovative wagasa "magnifying" tradition: light, compact, easy-to-take \& carry, foldable, and which diffuses beautiful and gentle light through washi paper.

This is in this specific context that K. Nishibori engages the firm in its first step of diversification: the "Kotori Lamp" project. The idea of a lamp product emerged through the combination of patient observing, crafting and market researching. The story goes that $\mathrm{K}$. Nishibori got the idea of making a lamp when he saw the beautiful light passing through the dyeing wagasa in the courtyard of the neighbourhood Buddhist temple.

However, the capacity of Hiyoshiya to develop a lamp product proved itself short; the first prototype consisted of a wagasa to which he simply has scratched a bulb and an electric cable ware. 'I realized very fast that I couldn't do it by myself and that I'd need the designer's help to develop new products. However, through this process, I knew, somehow, that the new product should be an umbrella-like product and come from our long-lasting tradition, our know-how and our production techniques. Otherwise, I will be loosing my identity' (Interview2, KN, June, 2011).

K. Nishibori first collaborated with a well-known interior designer, $\mathrm{M}^{\mathrm{r}}$ Nagane, introduced by a private consultant helping him to develop Hiyoshiya's brand. The collaboration with $\mathrm{M}^{\mathrm{r}}$ Nagane doesn't turned out to be as effective as expected. However, the designer gave him the idea of a 'tube shape', which was quite popular in the contemporary furniture business. 'The tube shape idea was fine and we made it ours; however, it was not good enough to create a strong brand image; it was also easy for the others to adopt it' (Op. cit.). He tried to convince $\mathrm{M}^{\mathrm{r}}$ Nagane to work further on the foldable mechanism of the "wagasa-lamp", which could make the lighting product unique. However, $\mathrm{M}^{\mathrm{r}}$ Nagane didn't go with well and the collaboration ended up. He tried to move on with its team.

Along the process of conception, K. Nishibori has started looking for public support to finance the project. His experience as a former public officer gives him access to all the public SMEs supporting programs. In 2007, he decides to apply for the 'Kyoto Premium' program initiated by the local Chamber of Commerce and Industry and sponsored by the Ministry of Economy, Trade and Industry (METI). The program aims at promoting traditional SMEs by financially supporting their R\&D activity in the field of interior design. Hiyoshiya was selected and becomes one of tenth Kyoto city 'ambassador' at two major interior design exhibition/fairs in France (Maison \& Objet) and Germany (Ambiente) the coming year. In these fairs, K. Nishibori will meet with $\mathrm{M}^{\mathrm{r}}$ Kusano, a very influential consultant, working part-time for the Jetro (Japan External Trade Organization) and who invites him to participate into the biggest fair in the United States (ICFF) in 2009.

Thanks to his opportunistic managing director, Hiyoshiya has been able to display his prototype and make it a real sellable product with the feedbacks received on these major exhibitions. The final product is welcomed throughout Europe and two distributors in Germany and in Holland consent to test the product on their local market. In the United States, a major distributor was interested but finally rejected the proposal. However, he submitted the following idea to K. Nishibori : 'To tell you the truth, I do like the idea, I find the concept quite interesting; I don't like the product; made of bamboo and paper, it is too traditional; however, if you can make it more contemporary, use new materials; then I will think about it' (Interview3-KN-July, 2011).

Along the Kotori project, and media exposure associated with its participation to the Japanese booths worldwide, K. Nishibori has been receiving some design collaborations from major designers. A famous object designer, $\mathrm{M}^{\mathrm{r}}$ Shimamura, comes up with a very simple idea: make a traditional umbrella an every day's product by using bamboo but also new materials. K. Nishibori joined enthusiastically the team project already composed of three members: the designer himself, a lacquer and a bamboo provider. In this project team, Hiyoshiya and K. Nishibori will be in charge of the assembling and the delivery of resulting new product - The sinaru umbrella.

Things really go fast: six months later the first meeting, a prototype is presented at the $100 \%$ Design Tokyo Exhibition (Oct. 2007). The product is then displayed 3 months later, without any change, at Maison \& Objet (Jan. 2008). The sinaru umbrella is welcomed and first orders have been taken (300 pieces), but without informing K. Nishibori, who was in charge of the production: 'We have not sold products but only prototypes which were not finalised prototypes. (...) I was just in charge of a part of the process, only a part of it. Changes were always brought to the prototype; things weren't fixed and couldn't be fixed. However, we had to deliver our customers who had passed order and we did it awfully' (Interview3-KN, July, 2011). As a result, there had been a real gap between the selling price fixed, at about $300 €$ per piece, and the expected quality of the product. 3 years after the launching of the sinaru umbrella, only half of the orders have been honoured; half of the products delivered have been returned and had to be paid back. "In most cases, the complaints from retail clients who had received defective products or 
who had not been delivered were sent to my company simply because it is easier for them to get in touch with me. The problem is that I couldn't fix it out and I couldn't have $M^{r}$ Shimamura worked on it. It had been really a kind of nightmare during one year and half." (Interview3-KN, July 2011). Anyway, the product continues to be available on sale on net shops. But as learning, in $2010 \mathrm{~K}$. Nishibori decides to withdraw from the project and promises himself to be only part of a project to which he can get control.

\subsubsection{8-2010: An Emerging Agency Power}

As a response to the American distributor's challenge, 'making a more contemporary kotori lamp with new materials', K. Nishibori firstly mobilized $\mathrm{M}^{\mathrm{r}}$ Nagane who declines the offer after an unsuccessful attempt; he then asked $\mathrm{M}^{\mathrm{r}}$ Kusano, the independent consultant, who introduced him a young and promising designer who works for the Muji Brand, $\mathrm{M}^{\mathrm{r}}$ Miyake. There is a real spark between them: they share the same age and the same vision of what should be design collaboration. They make a good start with the project so that they decide to call it 'mekatori' (mechanical kotori) to benefit from the public subsidies received for the development of the Kotori lamp.

The first prototype is made of bamboo, which makes easier adaptations and reduces the cost of development. It is showed to the American distributor early September 2009 who suggest making it of aluminium. The second prototype made of aluminium is presented early 2010 but is still not satisfying: it appears to be weak to the unfolding repeated movements. In addition, the lamp results in being heavy and really too costly to be made of aluminium. A third prototype, more convincing, is made of steel (fall 2010) then in ABS plastic (end 2010) which is adopted unanimously: the 'moto' lamp is born through this process of exploration and prototyping.

With regards to the conception and the production of the new lamp, K. Nishibori and his team initially planned to transpose the unfolding mechanism of the wagasa umbrella to the lamp. The advantage was twofold: it didn't cost a lot and the system has proved to be robust so far. $\mathrm{M}^{\mathrm{r}}$ Miyake has been working with a Chinese manufacturer who is able to produce it cheap. He personally takes in charge the process of prototyping, working closely with the manufacturer to bring the necessary steps to make it functional. Beyond the lamp structure, the team is also meeting problems with electrical devices. Differently from what they did for the Kotori lamp project, $\mathrm{K}$. Nishibori and $\mathrm{M}^{\mathrm{r}}$ Kusano decide to establish a long-term partnership with Fuji Denko company, a 99\% subsidiary of Koizumi Ligthing company for which K. Nishibori has been producing specific Kotori lamps. In a win-win strategy, Fuji Denko, which negotiates sourcing exclusivity, accepts to take in charge all the development costs underpinning electrical devices of the product.

Regarding fundraising of the project, K. Nishibori couldn't benefit from the initial public support granted to him for the kotori lamp project. They decided with $\mathrm{M}^{\mathrm{r}}$ Miyake to apply for different interior design prizes to get media coverage and new public support. Accordingly, they got the famous 'IMF prize' at the Frankfurt Ambiente Exhibition in January 2010, which helped greatly Hiyoshiya - who takes the lead of the project - to be selected to two new METI programs: the 'Japan Brand' program, which is specifically dedicated to innovative SMEs in order to develop new products by using traditional know-how, techniques and materials; And also, the 'Japan Style +' program, which is more 'design-oriented' and aims at helping SMEs to develop the design of their products. Thanks to these two programs, K. Nishibori could present their whole collection of wagasa, umbrellas and lamps, new but also older products, at two major exhibitions in Paris in 2011 (Japan Brand Paris Exhibition \& Japan Style + in Maison \& Objet, 2011). This was the opportunity to find new distributors and consolidate its existing distribution network throughout Europe. Those exhibitions helped Hiyoshiya to get in touch with new partners, in order to launch new projects: for instance, collaboration with the group LVMH was settled to develop a nomadic lamp based on the same unfolding principle of the historical wagasa.

Meanwhile, Hiyoshiya's participation to European exhibitions in 2008 also gave K. Nishibori the opportunity to get in touch with the German designer, Jörg Gessner, who presents many advantages. First, he is used to working with Japanese manufacturers of washi paper used in the making of wagasa. Then, he often goes to Japan to follow up projects. Second, he has his own showroom in Paris where he can present his own collections but also other designer's collections.

Regular meetings between the two make the collaboration easier; and all the more than the two sides agree to share the leadership of the project and benefit of each interpersonal networks. Accordingly, the designer was responsible of design, communication and marketing aspects; and K. Nishibori was more in charge of technical, production and financial aspects of the collaboration. As a result, they were able to show the 'Jörg Kotori' lamp at the Paris showroom in 2009 and it was the starting point of new lamp improvements. Variations of the 'Jörg Kotori' initial lamp are thus introduced at the Japan Brand exhibition and Maison \& Objet in 2011.

As for the development of the 'moto' lamp, it is worth noting that K. Nishibori insisted on keeping the kotori word in each of his project title in order to continue to benefit from the initial public support. 
More recently, their successful collaboration, so far, has incited them to make a proposal to the Hermès Group. It is during one of the private exhibitions that Jörg had made possible the meeting with one of the Hermès family member and K. Nishibori. They engage themselves in the development of a new lamp called 'butterfly', which would illuminate a new Hermès boutique in Paris from next fall 2012.

During this period, K. Nishibori had the opportunity to capitalize on the original success of the 'Kotori' Lamp. Contacts initiated in the first period and returns on experience on initial projects of diversification helped him to clarify routines and roles he has, to guarantee his commitment to new projects. These were the foundation of an emerging agency power, which he has to capitalize on.

\subsubsection{From 2010: Capitalization and Benefits of an Embedded Agency Power}

Meanwhile the development of the 'moto'lamp and willing to take the most of the 'sinaru' umbrella failure, K. Nishibori takes the decision in early 2010 to launch its own new umbrella project. Called 'Ryoten'- 'ryo' for '2, both' and 'ten' for 'weather' - the new eco-friendly umbrella offers a twofold advantage by protecting from the sun and the rain as the wagasa used to. The structure is composed of ABS ribs - the veal made of a bio-plastic highly resistant, waterproof, and anti-UV. Moreover, Ryoten is designed to be printable, which makes it an original and potential media support for Brands.

Contrary to the Sinaru project development, K. Nishibori is the project initiator and makes sure he can manage and get control of the whole process of production and distribution. He makes the choice to get along with $\mathrm{M}^{\mathrm{r}}$ Kusano, the independent consultant with whom he works for the Kotori lamp development. They both choose to work with a very young and promising Swiss designer, called Olivier Franz: who is available, lives in Japan, speaks Japanese, and who is enthusiastic to be part of the project.

The team takes the decision to only work with 'mature' suppliers with whom they have already been working for years. "On the sinaru project, Shimamura had chosen to collaborate with a Chinese producer which offered the best quality/cost ratio but that he never worked with; in the ryoten project, we chose a manufacturer that we know well and with whom Miyake and Muji had been working for more than 15 years" (Interview4-KN, July, 2011).

This is also a consequence of previous projects and business relationships that $\mathrm{K}$. Nishibori gets access to a bio-plastic supplier. Bio-plastic leaves are produced by Toyota Chemicals whose President, $\mathrm{M}^{\mathrm{r}}$ Shimura, has been introduced by $\mathrm{M}^{\mathrm{r}}$ Inoue: one of the former managing directors of Koizumi lighting Company for which K. Nishibori was producing specific Kotori lamps. " $M$ " Inoue has been very important for us; he has been introduced to me by $M$ " Nagane who has drown several products for him and Koizumi Lighting; he is a top manager with whom I feel very comfortable; he's got an eye on me since our first meeting years ago; by the way, it was at that time, after having finished talking about the Koizumi Kotori lamps, that I told you that I was looking for a synthetic or bio plastic provider" (Interview4-KN, July 2011).

Regarding the financing of the project, which couldn't benefit from public support for the development, $\mathrm{K}$. Nishibori took the decision to take almost everything in charge: Hiyoshiya is the main contributor indeed, even if the other team members have some part of it. Beyond the initial financial plan, K. Nishibori has always been thinking of improving the business model by controlling all the production and distribution costs. Contrary to the sinaru project during which the cost inflation prohibited them to have retailers, K. Nishibori introduced a higher commission percentage from the beginning to make sure the distributors will be attracted by the products and will make their best to promote it.

All in all, the ryoten project marks a milestone in the Hiyoshiya's international development. It has been the first project in which K. Nishibori really had full control of the whole process from the conception to the distribution including research and development, manufacturing, assembling. Since, he has only been involved in new projects that can be handled by himself in hand with long-term partners, designers, providers or distributors: he has launched a new tea house that he introduced at the Shanghai Exhibition in Autumn and he has been engaged for example with K. Miyake in the development of a new lamp for Louis Vuitton Malletier for approximately a year. These new products developments allow him to pursue its international development, which enable him to develop more products and be involved in new projects in turn: he will be presenting mid-April 2012 his new products collection successively at the Light \& Building Fair in Frankfurt and at Milano Salone Festival. Last year 2011 had been so far the best year ever for Hiyoshiya: its revenues increased almost $20 \%$, achieving $45 \%$ of its annual sales internationally.

To summarize all this, Figure 1 presents key innovation projects, internationalization phases and business networks in their chronology. Next section presents our selective coding and our synchronic analysis. 


\section{Results: A Synchronic Analysis of Entrepreneur's Embedded Agency into a Continuous Global Innovation System}

\subsection{Network-based Decision-making Process in Context of SME}

Previous researches have emphasized on importance of network relationships of decision-makers in regards to both innovation and internalization in context of SMEs (Collinson \& Houlden, 2005). Most of these researches focus on a utilitarian perspective of social networks' mobilization by entrepreneurs (Coviello \& Munro, 1997). Rather than a utilitarian approach, our case study stresses on a more 'effectual' perspective of the network-based decision-making process (Sarasvathy, 2008). Indeed, during first stages of Hiyoshiya's development, K. Nishibori starts from a bunch of resources at his hand (traditional know-how, social relationships formalized from his previous activity, awareness of financing programs...) to figure how he can deal with the adversity of the family workshop in a declining industry.

In order to get access to new resources (financial, designers, suppliers...) requisite for its innovations, K. Nishibori had to engage in return his firm in some counterparties. For example, financing programs of the METI helped K. Nishibori to fundraise its R\&D in exchange of becoming an ambassador of Japan in different exhibitions around the world. In fact, by leveraging direct business networks to access resources, K. Nishibori gets effectively access to these resources (designers, suppliers, clients...), and in return stretches his own business network. In that sense, the development of the firm depends on the original dotation of business networks in which the entrepreneur is embedded. Progressively, K. Nishibori gets in touch with famous designers, identifies relevant suppliers, while prestigious clients identify him as a relevant partner to work with.

Accordingly, the 'effectuation' rationality of decision-maker assumes the centrality of the entrepreneur in its ability to construct conditions of success along the way (Sarasvathy, 2001). By leveraging business networks in which he is embedded, the decision-maker stretches his social network and access to more remote resources as one goes along internationalization and innovations. This 'stretch and leverage' perspective of network-based decision making relies on a trial-and-error process of learning, during which the entrepreneur becomes progressively aware of his power of agency.

\subsection{Understanding Entrepreneurial Bricolage Processes}

In project activities, the trial-and-error process of learning relies on different bricolage processes. At first stage, when K. Nishibori took control of the family business, his first action was to do what he does the best: promotion and communication - implementing with his brother their know-how to develop the firm's Internet website. In the late 1990s, it was quite a breakthrough in this sector and it helped him to get in touch with new persons and interest groups. Leveraging creatively and voluntarily his personal know-how, even recombining the firm traditional know-how to the development of new products (lamps), prefigure conditions of entrepreneurial bricolage processes at work.

Each project contributes to clarify the process through which the entrepreneur creates/builds up conditions for his success. Obviously, even if the project turns out to be a failure, there is a place for learning. For example, the Sinaru Project helped K. Nishibori to identify precisely the importance to get control on key activities for future projects.

The longitudinal description of our case study reveals the ability of the entrepreneur to 'create something' from nothing by recombining more effectively whatever resources he has at hand (Baker \& Nelson, 2005). Firstly, the entrepreneur accumulates resources (materials, business relationships, financial), which extend the range of possibilities. Secondly, this process of accumulation relies on discursive strategies with key actors. These meetings held with designers on exhibitions and exchanges with consultants and institutional partners create opportunities and provides K. Nishibori new resources. Finally, success breeds success. First prototypes convince 'artifacts', which contribute to give credibility to Hiyoshiya in its new business network. This reflexive learning on projects helps K. Nishibori to understand maneuvers and strategies to guarantee success of his involvements.

Consequently, internationalization and innovation were more results than causalities underlying decision-making of an entrepreneur in a doomed industry. Trial-and-error processes and bricolage processes underlying projects and prototyping in which he engages his firm, design the trajectory of both internationalization and innovation.

\subsection{The Entrepreneur's Embedded Agency: Toward a Global System of Continuous Innovation}

Neo-institutional literature reveals a 'paradox of embedded agency' to address challenges of change in institutional fields (Battilana \& D'Aunno, 2009). K. Nishibori was able to extract his firm from taken for granted historical practices of his institutional field because he was initially an outsider. This movement of regeneration and change in the industry rely on interlocking business networks and involvement in projects of diversification according to a traditional know-how. Entrepreneur's vision is focused on the survival of the family business in a doomed industry. 
As we mentioned earlier, K. Nishibori considers that: "Tradition is a continuous movement of innovation". Each project and each relationship were oriented to nurture this vision and get physical evidence in terms of innovation on products (Lamps) and markets (internationalization). Each project, in which he engages his firm, conduct $\mathrm{K}$. Nishibori to get conscious and develop a competency of an international project manager. These competencies reinforce his position in a global system of continuous innovation. Accordingly, as Figure 1 present it, the more Hiyoshiya innovates and the more effective Hiyoshiya is in its time-to-market (represented by dotted lines before projects on the figure).

Hiyoshiya is now still one of the last firms performing on the traditional know-how of wagasa. Its trajectory in terms of diversification reveals opportunities for other firms in the industry. For example, Hiyoshiya's main competitor, Fujisawa company, has very recently engaged in a diversification of traditional wagasa umbrellas to the interior design industry with tables based on the traditional know-how. Accordingly, K. Nishibori has acted so far as an institutional entrepreneur without a clear consciousness of the implications of his actions on its industry and the taken for granted practices in the traditional wagasa industry. However, it is clear enough that its successes in the interior design industry have introduced new practices in the wagasa industry: co-development with designers, a global market approach of the business, working with new suppliers, promotion of Japanese innovation based on traditional know-how.

\section{Discussion}

\subsection{Understanding Globalization and Innovation Dynamics of SMEs under Consideration of Entrepreneur's Agency} Power

According to the mainstream of research, the Uppsala Model (Johanson \& Vahlne, 2009) provides with a linear and sequential process of internationalization with incremental learning (Keupp \& Gassmann, 2009; McDougall \& Oviatt, 2000). As mentioned earlier, even the proponents of the International Entrepreneurship School (Rialp, Rialp, Urbano \& Vaillant, 2005; Knight \& Cavusgil, 2004; Sharma \& Blomstermo, 2003) have difficulties reaching a different way of thinking. Hiyoshiya Case Study suggests a more complex dynamics in which innovation and internationalization combine each other to help the firm to develop worldwide. Internationalization was not part of entrepreneur's original intentions; it has become the principal kick-start to innovate as innovation turns out to be essential for its international development.

Furthermore, contrary to empirical studies which tend to confirm this statement without any consideration to the central role played in both internationalization and innovation (Bacq \& Coeurdevoy, 2010), the case study makes clear the role played by K. Nishibori in the decision making-process. The entrepreneur has not a clear understanding of the role he has to play from the beginning; he takes conscious of its role and his agency power progressively by getting involved himself in different projects and building relationships.

Committed to projects, he first uses resources at hand and then learns through bricolages and in relationships as its business network expands. In other words, he has been acting and taking his decisions more in an effectual way trying to transform possibilities into business opportunities (Sarasvathy, 2001, 2008) than in a strictly causal decision making process. As, Sarasvathy mentioned that: "effectual reasoning does not begin with a specific goal. Instead, it begins with a given set of means allows goals to emerge contingently over time from the varied imagination and diverse aspirations of the founders and the people they interact with." (Sarasvathy, 2001). Accordingly, if innovation and internationalization decision making reveal itself through time, our case study explores and reveals some processes at work and interlocking business networks, artifacts and entrepreneur's aspirations.

\subsection{Implications for Entrepreneurs: Enhancing Their Agency Power}

The research through this case study suggests that the internationalization could be a good opportunity for entrepreneurs to expand their business networks to help them to innovate and better respond to markets needs. However, this opportunity relies on the ability of the entrepreneur to get and develop their agency power. As we pointed out, entrepreneurs should make sure that they can get themselves, or in collaboration with long-term partners, fully control of the process of innovation and internationalization.

This agency power rests on entrepreneurs' capacity to exploit their own resources that they had at hand and to explore new remote resources that they need to innovate and go global. Doing so, they need to develop 'political skills' as they mainly can get access to these resources through networking and building long-term relationships.

This research also highlights for the entrepreneurs the importance of intuition, improvisation, bricolages and other skills to be able to recognise the positive changes they are facing with and take the most of the emerging opportunities in or out their industry. 


\subsection{Methodological Limits and Research Agenda}

This research relies on a single case study, which is coherent with the choice of an exploratory study. However, it is necessary to explore other case studies embedded in different contexts to be able to generalize the results of this exploratory study. Presently, Hiyoshiya innovation trajectory has influenced other competitors to get involved in new product development. The leader of the market, Fujisawa company, is now trying to develop a new table based on the unfolding principle of the wagasa. Other smaller companies are also exploring new options for diversification. The study of these new trajectories will allow a more global view on the impact of the Hiyoshiya innovative strategy in its institutional context.

We must also mention a potential cultural effect as a long-lasting tradition of internationalization in Japan may alter the preliminary results of the case study and put too much emphasise on internationalization in Hiyoshiya strategic trajectory and other company efforts to get out of their critical situation.

This research was purely exploratory regarding the theoretical background and a symbolic trajectory of an entrepreneur. Our research goal was to understand and explain the singular trajectory of an entrepreneur in a doomed industry and dynamics by which he transformed a dead-end situation to a global system of continuous innovation. Our results emphasize on an effectual rationality of the entrepreneur, which decision-making processes are embedded in his interactions with his expanding business network and artifacts from bricolage processes. Accordingly, we need further researches and case studies to describe SMEs' effectual rationality at work in context of innovation and internationalization.

\section{References}

Bacq, S., \& Coeurderoy, R. (2010). La théorie de l'entreprise à internationalisation rapide et précoce à l'épreuve des faits: évaluation de l'apport des travaux empiriques à ce champ de recherché. RIPME:Revue International des PME, 23(1), 91-124.

Baker, T., \& Nelson, R. E. (2005). Creating Something from Nothing: Resource Construction through Entrepreneurial Bricolage. Administrative Science Quarterly, 50(3), 329-366. http://dx.doi.org/10.2189/asqu.2005.50.3.329

Battilana, J., \& D'Aunno, T. (2009). Institutional work and the paradox of embedded agency. In Lawrence T. B., Suddaby R. \& Leca B. (Eds.), Institutional Work: Actors and Agency in Institutional Studies of Organizations (Chapter 2, pp. 31-58). Cambridge: Cambridge University Press. http://dx.doi.org/10.1017/CBO9780511596605.002

Beckert, J. (1999). Agency, entrepreneurs, and institutional change: The role of strategic choice and institutionalized practices in organizations. Organization Studies, 20(5), 777-799. http://dx.doi.org/10.1177/0170840699205004

Burawoy, M. (1998). The extended case method. Sociological Theory, 16(1), 4-33. http://dx.doi.org/10.1111/0735-2751.00040

Campbell, D. T., \& Fiske, D. W. (1959). Convergent and discriminant validation by the multitrait-multimethod matrix. Psychological Bulletin, 56, 81-105. http://dx.doi.org/10.1037/h0046016

Collinson, S., \& Houlden, J. (2005). Decision-making and market orientation in the internationalization process of small and medium-sized enterprises. MIR: Management international Review, 45(4), 413-436.

Coviello, N. E., \& McAuley, A. (1999). Internationalization and the smaller firm: A review of contemporary empirical research. Management International Review, 39(3), 223-256.

Dana, L. P. (2004). Handbook of Research on International Entrepreneurship. Northampton: Edward Elgar Publishing.

Danneels, E. (2002). The dynamics of product innovation and firm competences. Strategic Management Journal, 23(12), 1095-1121. http://dx.doi.org/10.1002/smj.275

Delemarle, A. (2007). Les leviers de l'action de l'entrepreneur institutionnel: Le cas des micro et nanotechnologies et du pôle de Grenoble. (Thèse doctorale). Ecole Nationale des Ponts et Chaussées.

Dorado, S. (2005). Institutional entrepreneurship, partaking, and convening. Organization Studies, 26(3), 385-414. http://dx.doi.org/10.1177/0170840605050873

Eisenhardt, K. M. (1989). Building theories from case study research. Academy of Management Review, 14(4), 532-550. http://dx.doi.org/10.2307/258557

Garud, R., \& Karnoe, P. (2001). Path creation as a process of mindful deviation. In Garud, R. and Karnoe, P. (Eds.), Path dependence and Creation (pp. 1-38). Lawrence Earlbaum Associates. 
Gombault, A. (2006). La méthode des cas. In Roussel P. \& Wacheux F. (Eds.), Management des ressources humaines. Méthodes de recherche en sciences humaines et sociales. Bruxelles: Editions de Boeck Université.

Holm, P. (1995). The dynamics of institutionalization: Transformation processes in Norwegian Fisheries. Administrative Science Quarterly, 40(3), 398-422. http://dx.doi.org/10.2307/2393791

Jick, T. D. (1979). Mixing qualitative and quantitative methods: Triangulation in action. Administrative Science Quarterly, 24, 602-611. http://dx.doi.org/10.2307/2392366

Johanson, J., \& Vahlne, J.-E. (1977). The internationalization process of the firm: a model of knowledge development and increasing foreign market commitments. Journal of International Business Studies, 8(1), 23-32. http://dx.doi.org/10.1057/palgrave.jibs.8490676

Johanson, J., \& Vahlne, J.-E. (1990). The Mechanisms of Internationalization. International Marketing Review, 7(4), 11-24. http://dx.doi.org/10.1108/02651339010137414

Johanson, J., \& Vahlne, J.-E. (2009). The Uppsala internationalization process model revisited: From liability of foreignness to liability of outsidership. Journal of International Business Studies, 40, 1411-1431. http://dx.doi.org/10.1057/jibs.2009.24

Keupp, M., \& Gassmann, O. (2009). The past and the future of international entrepreneurship: A review and suggestions for developing the field. Journal of Management, 35(3), 600-633. http://dx.doi.org/10.1177/0149206308330558

Knight, G., \& Cavusgil, S. T. (2004). Innovation, organizational capabilities and the born global firm. Journal of International Business Studies, 35, 124-141. http://dx.doi.org/10.1057/palgrave.jibs.8400096

McDougall, P. P., \& Oviatt, B. (2000). International entrepreneurship: The intersection of two research paths. Journal of Small Business Management, 43(5), 902-909.

McGaughey, S., Welch, D., \& Welch, L. (1997). Managerial Influences and SME Internationalization. In Bjorkman, I. \& Forsgren, M. (Eds.), The Nature of the International Firm (pp. 165-188). Copenhagen: Handelshojskolens Forlag.

Rialp, A., Rialp, J., Urbano, D., \& Vaillant, Y. (2005). The born global phenomenon: A comparative case study research. Journal of International Entrepreneurship, 3, 133-171. http://dx.doi.org/10.1007/s10843-005-4202-7

Sarasvathy, S. D. (2001). Causation and Effectuation: Toward a theoretical shift from economic inevitability to entrepreneurial contingency. Academy of Management Review, 26(2), 243-288. http://dx.doi.org/10.2307/259121

Sarasvathy, S. D. (2008). Effectuation: Elements of Entrepreneurial Expertise. Northampton: Edward Elgar, New Horizons in Entrepreneurship Series.

Schackle, G. L. S. (1979). Imagination and the nature of choice. Edinburgh: Edinburgh University Press.

Seo, M. G., \& Creed, W. E. D. (2002). Institutional contradictions, praxis, and institutional change: a dialectical perspective. Academy of Management Review, 27(2), 222-247. http://dx.doi.org/10.2307/4134353

Sharma, D., \& Blomstermo. A. (2003). The internationalization process of born globals: a network view. International Business Review, 12(6), 68-82. http://dx.doi.org/10.1016/j.ibusrev.2003.05.002

Yin, R. (1990). Case study research: design and methods. London: Sage Publications. 


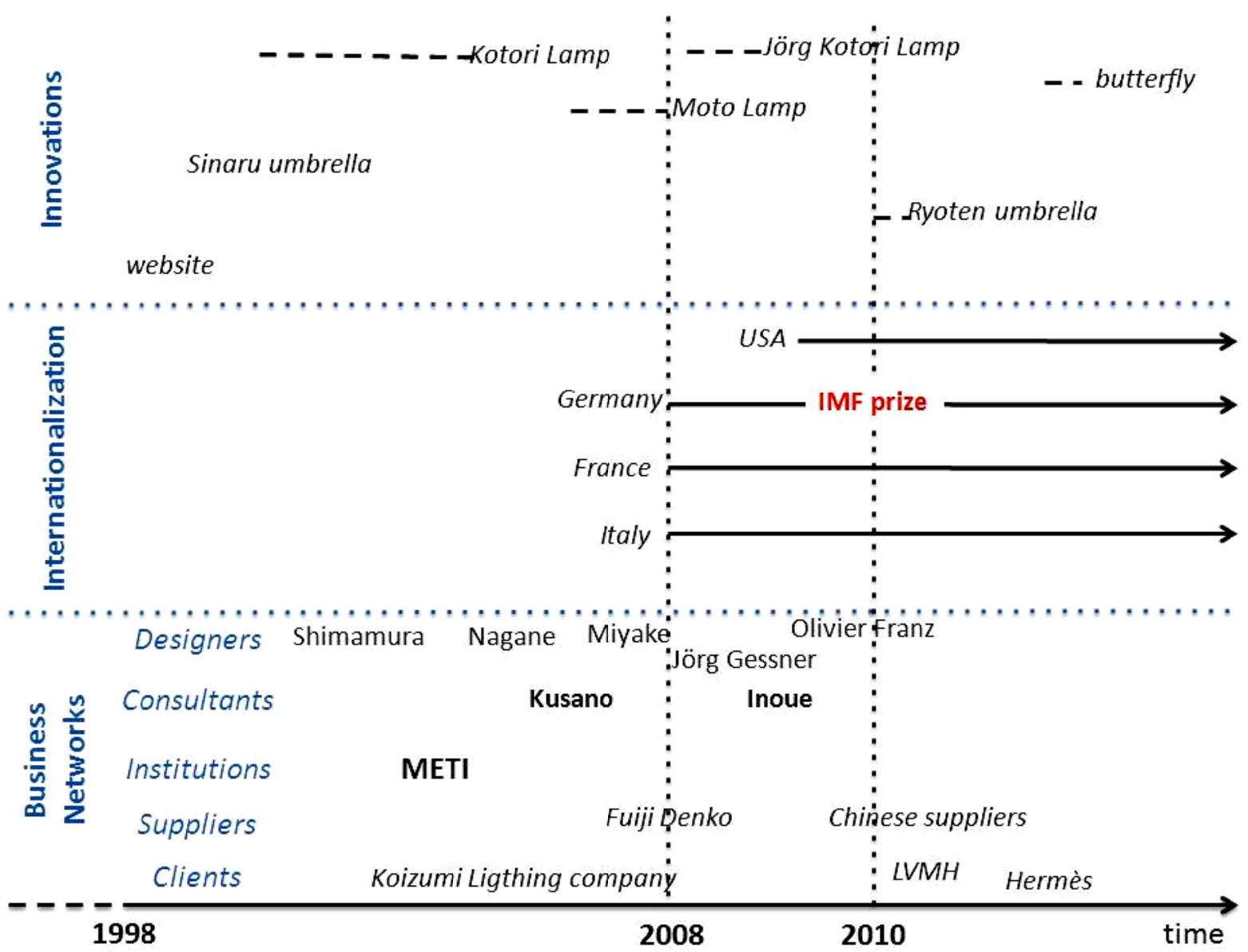

Figure 1. Hiyoshiya's trajectory of innovation and internationalization under consideration of its Business Network expansion 